\title{
Technical Feasibility of Biodiesel Production From Waste Cooking Oil: Comparison Between Electric Heating and Microwave Heating Process
}

\section{Wenjing Li}

Tongji University College of Environmental Science and Engineering

Guangming Li ( $\sim$ ligm@tongji.edu.cn)

Tongji University https://orcid.org/0000-0002-0281-8258

\section{Fan Wang}

Chinese Research Academy of Environmental Sciences

\section{Haochen Zhu}

Tongji University College of Environmental Science and Engineering

Wenzhi He

Tongji University College of Environmental Science and Engineering Juwen Huang

Tongji University College of Environmental Science and Engineering

\section{Research Article}

Keywords: Electric heating and Microwave techniques, Kinetic analysis, Process optimization WCO, Variance Analysis

Posted Date: October 8th, 2021

DOl: https://doi.org/10.21203/rs.3.rs-863803/v1

License: (c) (i) This work is licensed under a Creative Commons Attribution 4.0 International License. Read Full License 
1 Technical feasibility of biodiesel production from waste cooking oil: Comparison between

electric heating and microwave heating process

3

4 Wenjing $\mathrm{Li}^{\mathrm{a}}$, Guangming Li ${ }^{\mathrm{a}, *}$, Fan Wang ${ }^{\mathrm{c}}$, Haochen Zhu ${ }^{\mathrm{a}}$, Wenzhi He ${ }^{\mathrm{a}}$, Juwen Huang

$5 \quad{ }^{\mathrm{a}}$ College of Environmental Science and Engineering, Tongji University, 1239 Siping

6 Road, Shanghai, 200092, China

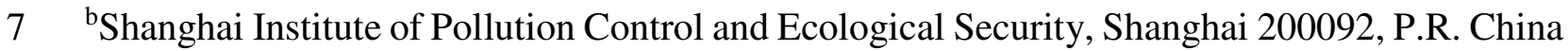

$8{ }^{\text {c}}$ Chinese Research Academy of Environmental Sciences, No. 8, Dayangfang, Beiyuan, Anwai,

9 Chaoyang District, Beijing, China.

10 . Corresponding Author: Prof. Guangming Li, Ph D

11 Corresponding Author's Affiliation: College of Environmental Science and Engineering,

12 Tongji University, 1239 Siping Road, Shanghai, 200092, China.

13 Corresponding author E-mail: ligm@tongji.edu.cn; Phone: +86 13501967237; Fax: +021

$14 \quad 65989215$

15 Abstract: Base-catalyzed transesterification and conversion of waste cooking oil (WCO) into

16 biodiesel is a renewable energy production technology with a wide range of applications. The

17 most commonly used heating method is electric heating (EH). Microwave heating (MW) has

18 the characteristics of high heat transfer efficiency and short preheating time, and has recently

19 received attention in this field.This study compared effects of the alkali-catalyzed

20 transesterification reaction of WCO under EH and MW processes. The maximum biodiesel

21 yield of $\mathrm{EH}$ process appeared when the reaction temperature is $60{ }^{\circ} \mathrm{C}$, the reaction time is 30 
min, the molar ratio of alcohol to oil is $6: 1$, and the catalyst concentration is $1.0 \%$, up to $93.4 \%$.

The maximum biodiesel yield obtained from MW technique is $80.66 \%$, under the condition of 200W, 5min, 1wt. \% KOH and the methanol/oil molar ratio of 9:1. The activation energy for

$\mathrm{CH}$ and MW process are found to be $6768 \mathrm{~J} \cdot \mathrm{mol}^{-1}$ and $503.4 \mathrm{~J} \cdot \mathrm{mol}^{-1}$, respectively. Microwave heating greatly reduced the activation energy of the reaction, as well as transesterification yield.

Compared with other biodiesel producing process, EH process in this study has the advantages of high speed and low production cost, while biodiesel yield is slightly insufficient. This is likely due to the small amount of un-removed moisture contained in the WCO.

Keywords: Electric heating and Microwave techniques, Kinetic analysis, Process optimization WCO, Variance Analysis

\section{Introduction}

Due to rapid population growth and economic growth in the last two decades, the consumption of edible oils has increased from 7,337,900 t (1999) to 50,660,000t (2018) in China (China 2018). Waste cooking oils (WCO) weighs approximately $25 \%$ of the total mass of edible oils production, while the output of WCO can reach 12,665,000 $\mathrm{t}$ in 2018 . WCO would be produced by pyrolysis, oxidation, and hydrolysis reactions occur during cooking and frying (Cvengros and Cvengrosova 2004, Maddikeri, Pandit et al. 2012), which bringing the increase of viscosity, specific heat, surface tension, and changes of color, and the formation of foam in oils (Kulkarni and Dalai 2006). Oils became a mixture of triglycerides with higher acid value, saturation and harmful contents (Xingguo 2013). Direct emission of WCO can cause a series of environmental 
43 (Peiro, Mendez et al. 2008). Worse still, because of the huge economic benefit (around 300\%

44 (Bussness 2012)) of trench oil, the unhealthy WCO that supposed to be disposed was reused

45 as edible oil after facile process, which seriously threatens human health (Math, Kumar et al.

46 2010).

47 WCO can be employed as raw materials to produce biodiesel, fatty acids and soaps, or as C sources in the production of single-cell proteins(Yinxia, Jian et al. 2009, fei and maiqian 2011)

49 and bio surfactants(Jia, Xiangfeng et al. 2009, Yao and Min 2010). Transesterification into

50 biodiesel is fast becoming a key instrument in WCO management. In the past few years, fresh

51 edible oils and non-edible oils are common raw materials for biodiesel production (Chuah,

52 Klemes et al. 2017, Putra, Irawan et al. 2018). However, these materials account for about $80 \%$

53 cost of biodiesel production, which is a lot higher than fossil fuel (Farid, Hassan et al. 2017,

54 Naylor and Higgins 2017). This fact makes WCO an anticipated material for biodiesel

55 production. As one of the most widely used technologies, homogeneous base catalysts-

56 potassium hydroxide $(\mathrm{KOH})$ or sodium hydroxide $(\mathrm{NaOH})$ can produce biodiesel at a mild

57 reaction temperature and pressure in short time. (Fadhil and Ali 2013, Mardhiah, Ong et al.

58 2017, Akram, Singh et al. 2019, Harabi, Bouguerra et al. 2019, Rajagopalachar, Joshi et al.

$592019)$

60 During the transesterification reaction, the heating method will affect the mass transfer and

61 heat transfer coefficient, thereby affecting the reaction efficiency. Among them, electric

62 heating $(\mathrm{EH})$ and microwave heating $(\mathrm{MW})$ are two common reaction processes. It was

63 reported that MW could provide a better thermal conductivity and convection currents 
64 generated in the mixture, and the requirement of pre-heating of reactants is not required.

65 (Milano, Ong et al. 2018, Silitonga, Shamsuddin et al. 2020)

66 However, currently, there are relatively few studies on the influencing factors, yield and

67 kinetics of the $\mathrm{CH}$ process and MW process. Due to the differences in the reaction materials,

68 reaction conditions and the operating level of the experimenters, the results of different studies

69 lack contrast, and it is difficult to scientifically reflect the difference in the transesterification

70 yields of the two processes. Therefore, this study uses WCO obtained from canteens and nearby

71 restaurants as raw materials, and $\mathrm{EH}$ and $\mathrm{MW}$ technologies were utilized to perform

72 transesterification to prepare biodiesel. This study will perform single factor experiments to

73 examine details in the influencing factors and reaction kinetics of the two technologies, and

74 thoroughly analyze the advantages and disadvantages of the two comparison. On this basis, the

75 acquired best yield will be compared with previous research results to have an insight on the

76 application potential of the raw materials used in this study.

$77 \quad 2$ Materials and methods

78 The waste edible oil used in the experiment comes from a student canteen of Tongji University.

79 In order to ensure the uniformity of the samples, 3 samples were taken from lunch, another 3

80 were taken from dinner. The collection process continued for 7 days from Monday to Sunday.

81 Total 42 samples were gathered and mixed into one WCO sample. Before transesterification,

82 the filtration and extraction were done to remove the contaminants and water. The procedure

83 of pretreatment is demonstrated in Fig.1. 


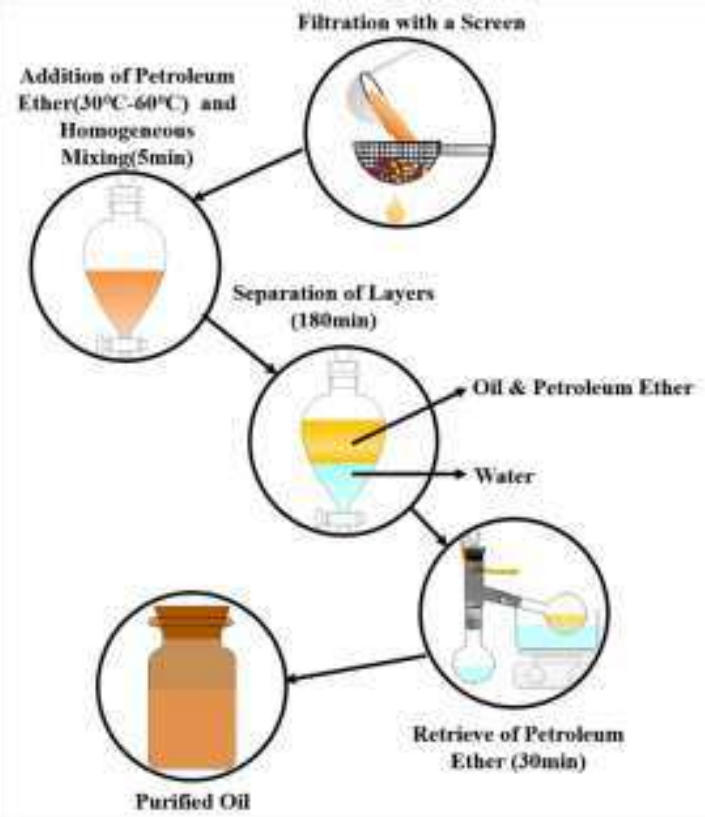

Fig.1. Oil Pretreatment to remove the contaminants and water

87 The methanol, the hexane for Gas Chromatography were obtained commercially from Sigma-

88 Aldrich (USA) and the analytical internal standard, heptadecanoic methyl ester was purchased

89 from Fluka (USA). The high-purity nitrogen was provided by Chunyu Special Gases Co., Ltd.

90 (Shanghai).

$91 \quad 2.1$ Characterization of the WCO

92 The characterization techniques were used to indicate the feasibility of the WCO for biodiesel

93 production. QP2010SE gas chromatography-mass spectrometer was employed to determine

94 WCO fatty acid profile. Nicolet5700 Fourier Infrared Spectrometer was used to determine

95 WCO molecular structure. The physical and chemical properties (density, acid value,

96 saponification value, peroxide value, iodine value and moisture content) was determined by

97 titration. These parameters were compared with common biodiesel raw materials. 


\subsection{Transesterification reaction}

99 Three neck flat bottom borosil flasks $(250 \mathrm{~mL}$ capacity) fitted with a condenser and a

100 temperature sensor were use in both reaction vessels. A magnetic bar was put into the reactor

101 for stirring and the stirrer was set at $700 \mathrm{rpm}$ as well. Transesterification reaction for

102 conventional heating $(\mathrm{CH})$ process was carried in a water-bath heating system. The oil was

103 preheated to the specified temperature to keep the reaction temperature stable, while methanol

104 and $\mathrm{KOH}$ were mixed in advance. Transesterification reaction for microwave heating (MW)

105 process was carried under $2450 \mathrm{MHz}$ microwave radiation. The oil and the $\mathrm{KOH}$-dissolved

106 methanol was mixed into the reactor at the beginning of reaction because of the high

107 temperature rise rate.

108 The transesterification was carried at the fixed mixing intensity (700 rpm), varying the catalyst

109 amount (0.5-2 wt. \%), methanol/oils molar ratio (3:1-15:1), reaction time (5-60 min for $\mathrm{CH}$,

110 and $0.5-30 \mathrm{~min}$ for $\mathrm{MW}$ ), reaction temperature $\left(50-70{ }^{\circ} \mathrm{C}\right.$ for $\left.\mathrm{CH}\right)$. Since there was no

111 temperature-controlled system installed in the microwave oven, it was not possible to maintain

112 the experimental temperature at a fixed value. So microwave power was fixed in the range of

113 50-500W in MW process. The biodiesel was split up immediately through cool water after

114 reaction, then filtered through $0.45 \mathrm{~mm}$ syringe filter.

\section{$115 \quad 2.4$ Analytical of biodiesel yield}

116 The FAME of biodiesel can be determined by gas chromatography mass spectrometry. The

117 analysis conditions were as follows: HP5-MS column; injection volume $1 \mu \mathrm{L}$; inlet temperature

$118260^{\circ} \mathrm{C}$; carrier gas is high-purity nitrogen, flow rate $50 \mathrm{~mL} / \mathrm{min}$, split ratio 19.9: 1 . The column 
119 thermostat uses a column heating program: initial temperature $70^{\circ} \mathrm{C}$, hold for $2 \mathrm{~min}, 10^{\circ} \mathrm{C} /$

$120 \min$ to $180^{\circ} \mathrm{C}$, then $5^{\circ} \mathrm{C} / \min$ to $230^{\circ} \mathrm{C}$, hold for $10 \mathrm{~min}$; detector is FID, temperature is

$121260^{\circ} \mathrm{C}$; hydrogen flow rate is $25 \mathrm{~mL} / \mathrm{min}$, The air flow rate is $300 \mathrm{~mL} / \mathrm{min}$.

122 The analytical internal standard for the quantitative determination was heptadecanoic methyl

123 ester. The peak areas of the internal standard and other esters were compared to quantify the

124 fatty acid methyl ester content in the biodiesel sample. The results were calculated according

125 to Eq.1.

$126 C=\frac{\sum A-A_{\mathrm{EI}}}{A_{\mathrm{EI}}} \times \frac{C_{\mathrm{EI}} \times V_{\mathrm{EI}}}{m} \times 100 \%$

127 Where $\mathrm{C}$ is the fatty acid methyl content $(\%) ; \sum \mathrm{A}$ is the total peak area; $\mathrm{A}_{\mathrm{EI}}$ is the peak area of

128 the heptadecanoic methyl ester; $\mathrm{C}_{\mathrm{EI}}$ is the concentration of heptadecanoic methyl ester in the

129 hexane $(\mathrm{mg} / \mathrm{L}) ; \mathrm{V}_{\mathrm{EI}}$ is the injection volume of heptadecanoic methyl ester solution $(\mu \mathrm{L}) ; \mathrm{m}$ is

130 the mass of biodiesel sample (mg).

$131 \quad 2.5$ Kinetics study

132 In the transesterification reaction, stoichiometrically 1 mol of triglycerides (TG) reacts with 3

$133 \mathrm{~mol}$ of $\mathrm{MeOH}$ to yield $3 \mathrm{~mol}$ of FAME and $1 \mathrm{~mol}$ of glycerol. The whole transesrification

134 reaction process can be written as Eq.2.

$135 \mathrm{TG}+3 \mathrm{MeOH} \stackrel{\text { KOH }}{\longleftrightarrow 3 F A M E+\text { Glycerol }}$

136 The geneal rate equation for the transesterification reaction can be expressed as Eq.3:

$137 \quad \frac{d[T G]}{d t}=k_{r}[T G]^{n} \mathrm{MeOH}$

138 where $\mathrm{t}$ is reaction time, $k_{r}$ represents the rate content.

139 The rate equation can be rewritten as Eq.4: 
$140 \quad \frac{d[T G]}{d t}=k_{r}[T G]^{n}=A \exp \left(\frac{-E_{a}}{R T}\right)[T G]^{n}$

141 where $\mathrm{t}$ is reaction time, $k_{r}$ represents the rate content.

142 In the $\mathrm{CH}$ process, homogeneous base-catalyzed reaction, $\mathrm{KOH}$ is dissolved in methanol in

143 advance, and the effect of stirring makes the entire reaction system be regarded as a

144 homogeneous reaction. For the molar concentration of methanol is much higher than the

145 stoichiometric requirement during the whole reaction, the concentration of methanol can be

146 treated as a constant. And the second-order transesterification can be regarded as a pseudo-first

147 order reaction (Ramezani, Rowshanzamir et al. 2010, Zhang, Sheng et al. 2010).

148 The rate equation for a pseudo-first order model $(n=1)$ can be expressed as Eq.5:

$149 \quad[\mathrm{TG}]=[\mathrm{TG}]_{0} e^{-k_{r} t}$

150 As for the MW process, it has been reported that under certain microwave power conditions,

151 the reaction follows pseudo-second-order reaction kinetics (Yeong, Law et al. 2019). The

152 integrated rate equation can be written as Eq.6:

153 After dividing left and right by $[\mathrm{TG}]_{0}$ at the same time, the rate equation can be expressed as

154 Eq.6:

$155 \frac{1}{[T G]}=\frac{1}{[T G]_{0}}+k_{r} t$

156 The activation energy of the reaction was calculated using the Arrhenius equation (Eq.7).

$157 k=A e^{-\frac{E_{a}}{R T}}$

158 Take the logarithm of both sides:

$159 \ln k=-\frac{E_{a}}{R T}+C$

$160 \quad 3$ Results and discussion 


\subsection{WCO characterization}

162 Table 1 provides the results of WCO characterization. To illustrate its potential for producing

163 biodiesel, the quality parameters were compared with waste oils used in other biodiesel prodect

164 reactions.

165 GC chromatogram showed the main chemical components of the WCO acid profile. Compared

166 with other waste edible oils which were used in biodiesel product, the fatty acid composition

167 of the waste oil in this study is more complex. While the main ingredients are fatty acids of

168 C16 to C20, accounting for $96.55 \%$, it still has the potential to be converted into biodiesel.(Yen,

169 Hu et al. 2013)

170 Acid value and moisture content are important indicators to characterize the properties of WCO.

171 Excessive free fatty acids will react with the alkali catalyst $\mathrm{KOH}$, and the water in the oil will

172 also promote the saponification reaction, reducing the yield of biodiesel produced by the

173 transesterification reaction. The threshold values of the acid value and moisture content of the

174 feedstock oil for homogeneous base-catalyzed transesterification are respectively $0.06 \%$

175 (Canakci and Van Gerpen 1999) and 1\% (2 $\left.\mathrm{mg} \mathrm{KOH} \bullet \mathrm{g}^{-1}\right)$ (Maddikeri, Pandit et al. 2012).

176 According to Table 1, the acid value of all feedstocks is less than the threshold value moisture

177 content, which shows that the raw materials in the table are suitable for the production of

178 biodiesel by homogeneous base catalytic transesterification. Especially, after pretreatment, the

179 acid value of our $\mathrm{WCO}$ is $0.4 \mathrm{mg} \mathrm{KOH} \bullet \mathrm{g}^{-1}$. It is possible to obtain a higher FAME yield

180 biodiesel in this study. 
181 The density of the WCO is lower than other waste oils, and the saponification value is only

182 higher than that of Hekel fish oil, indicating that WCO has a longer carbon chain and higher

183 average molar mass. The low iodine value of WCO indicates that its degree of unsaturation is

184 low. The WCO has longer average carbon chain and lower degree of unsaturation, its biodiesel

185 would have a higher cetane number and strong oxidation stability.(Knothe 2005, Zhang, Pham

186 et al. 2019) Compared with other non-edible feedstock, the WCO had higher potential for

187 biodiesel production.

188 In addition, further experiments on the effect of moisture content would be discussed in 3.2.3.

189

190 Table 1 The quality parameters of WCO and the comparison with the properties of waste

191 grease used in other studies

\begin{tabular}{|c|c|c|c|c|}
\hline Quality Parameters & WCO & $\begin{array}{l}\text { Fried Oil in Spain } \\
\text { (Bouaid, Vázquez } \\
\text { et al. 2016) }\end{array}$ & $\begin{array}{l}\text { Fried Oil in } \\
\text { Turkey (Uzun, } \\
\text { Kılıç et al. } \\
\text { 2012) }\end{array}$ & $\begin{array}{l}\text { Hekel Fish Oil } \\
\text { (Fadhil and Ali } \\
\text { 2013) }\end{array}$ \\
\hline \multicolumn{5}{|c|}{ Fatty acid composition } \\
\hline $\mathrm{C} 12: 0$ & 0.13 & - & - & 0.71 \\
\hline C14:0 & 1.00 & 0.28 & - & 1.48 \\
\hline C15:0 & 0.16 & - & - & 0.11 \\
\hline C16:0 & 13.64 & 15.01 & 7.07 & 10.53 \\
\hline C16:1 & 3.26 & - & - & - \\
\hline $\mathrm{C} 17: 0$ & 0.52 & - & - & 1.45 \\
\hline C18:0 & 8.82 & 4.66 & 2.42 & 4.20 \\
\hline C18:1 & 20.05 & 31.88 & 36.68 & 20.90 \\
\hline C18:2 & 29.68 & 42.56 & 52.20 & 14.06 \\
\hline $\mathrm{C} 18: 3$ & 3.32 & - & - & 9.28 \\
\hline C20:0 & 13.89 & 0.26 & - & - \\
\hline C20:1 & 1.79 & - & - & - \\
\hline $\mathrm{C} 20: 2$ & 0.69 & - & - & 0.86 \\
\hline C20:4 & 0.89 & - & - & 7.07 \\
\hline $\mathrm{C} 20: 5$ & - & - & - & 7.82 \\
\hline
\end{tabular}

10 


\begin{tabular}{|c|c|c|c|c|}
\hline Quality Parameters & WCO & $\begin{array}{l}\text { Fried Oil in Spain } \\
\text { (Bouaid, Vázquez } \\
\text { et al. 2016) }\end{array}$ & $\begin{array}{l}\text { Fried Oil in } \\
\text { Turkey (Uzun, } \\
\text { Kılıç et al. } \\
\text { 2012) }\end{array}$ & $\begin{array}{l}\text { Hekel Fish Oil } \\
\text { (Fadhil and Ali } \\
\text { 2013) }\end{array}$ \\
\hline C22:0 & 1.05 & 0.23 & 0.83 & - \\
\hline $\mathrm{C} 22: 5$ & - & - & - & 3.95 \\
\hline C22:6 & - & - & - & 2.21 \\
\hline $\mathrm{C} 24: 0$ & 0.42 & 0.08 & - & - \\
\hline \multicolumn{5}{|c|}{ Physicochemical properties } \\
\hline $\begin{array}{l}\text { Density } \\
(\mathrm{g} \bullet \mathrm{m} 3)\end{array}$ & $0.913 \mathrm{a}$ & - & $0.963 b$ & $0.9156 \mathrm{c}$ \\
\hline $\begin{array}{l}\text { Acid Value } \\
\left(\mathrm{mg} \mathrm{KOH} \cdot \mathrm{g}^{-1}\right)\end{array}$ & 0.4 & 1.3 & 0.587 & 1.9 \\
\hline Saponification & & & & \\
\hline $\begin{array}{l}\text { Value }(\mathrm{mg} \mathrm{KOH} \bullet \mathrm{g}- \\
\text { 1) }\end{array}$ & 184.1 & - & 185 & 182.15 \\
\hline $\begin{array}{l}\text { Iodine value } \\
(\mathrm{g} \mathrm{I} 2 / 100 \mathrm{~g})\end{array}$ & 36.88 & 115 & 122 & 107 \\
\hline $\begin{array}{l}\text { POV } \\
(\mathrm{mmol} / \mathrm{kg})\end{array}$ & 13.67 & 3.45 & 84.38 & - \\
\hline $\begin{array}{l}\text { Moisture content } \\
(\%)\end{array}$ & 0.097 & 0.023 & - & - \\
\hline
\end{tabular}

$192 *$ - means no data available; a means the density at $20^{\circ} \mathrm{C}$; b means the density at $15^{\circ} \mathrm{C}$; c

193 means the density at $15.6^{\circ} \mathrm{C}$.

\section{$194 \quad 3.2$ Biodiesel production}

$195 \quad$ 3.2.1 Biodiesel yield of EH process

196 In case of $\mathrm{EH}$, the optimization of the factors including reaction temperature, reaction time,

197 catalyst amount and methanol/oil molar ratio. Fig.2 shows the variation into FAME yield. The

198 maximum biodiesel yield obtained from $\mathrm{CH}$ technique is $93.45 \%$, under the condition of $60^{\circ} \mathrm{C}$,

199 30min, the dosage of $1 \mathrm{wt} . \% \mathrm{KOH}$ and the methanol/oil molar ratio of $6: 1$. The detailed results

200 are shown in table S1.

201 Fig.2a indicated that FAME yield increased with the increase of temperature from 50 to $60^{\circ} \mathrm{C}$, 202 and further increase of temperature would reduce the biodiesel yield. J. Mercy Nisha Pauline 11 
et al. also reported that the maximum FAME yield was achieved at the same reaction temperature. (Mercy Nisha Pauline, Sivaramakrishnan et al. 2021) Higher temperature could accelerate the reaction and shorten the reaction time by favouring the number of collisions.

206 (Ma and Hanna 1999, Leung and Guo 2006) In addition, an increase in the temperature 207 decreased the viscosity of the reaction mixture, increasing alcohol-oils two-phase contact as well (Gupta and Rathod 2018). Further increase of reaction temperature would accelerate methanol volatilization, which brought the decline of the FAME content. High temperature would promote the occurrence of saponification may be another important reason (Phan and

\section{Phan 2008).}

212 When the reaction time was in the range of 5-60min, the reaction was very fast in the first 5

$213 \mathrm{~min}$, then the process slowed down and tilled the maximum methyl content at 30min (Fig.2b).

214 To further increase the reaction time from $30 \mathrm{~min}$ to $60 \mathrm{~min}$ had no further positive effect on

215 the methyl content, even led to a small reduction. In this study, prolonging the reaction time 216 would slightly decrease the FAME yield, but previous studies had different results. Agarwal.et 217 al. produced biodiesel from waste cooking oil under $\mathrm{KOH}$ catalyzed, and reported the best 218 reaction time was 60min.(Agarwal, Chauhan et al. 2012) Elango, R. K., et al. reported a 219 maximum of $94.9 \%$ FAME yield was obtained at $60{ }^{\circ} \mathrm{C}$ with $1.25 \%(\mathrm{w} / \mathrm{v}) \mathrm{KOH}$ catalyst and 220 1:12 oil: methanol molar ratio for 60 min of reaction. (Elango, Sathiasivan et al. 2019) The 221 reason for this difference could be that more excess methanol can promote the positive shift of 222 the chemical equilibrium for a longer period of time, resulting in higher yields. However, considering economy, 30min was still selected as the subsequent reaction. 
224 When methanol content raising from 3:1 to 15:1, the FAME yield could remain above $75 \%$ 225 (Fig.2c). The improvement of methanol/oils molar ratio could drive the reaction process in the 226 forward direction. Besides, when methanol content gets higher in the system, the more 227 methanol can stay in the system when temperature increasing. But, extra methanol would 228 dissolve more glycerin, increasing the glycerol concentration in the reaction system. (Milano, 229 Ong et al. 2018) The more methanol in the reaction system, the specific surface area of 230 methanol-oils turns less as well (Motasemi and Ani 2012). The maximum biodiesel yield of $23193.45 \%$ was achieved for 6:1 methanol/oil molar ratio.

232 As shown in Fig.2d, the reaction would not occur without catalyst, and lower concentration (0 233 to $0.5 \% \mathrm{w} / \mathrm{w}$ of oils) of $\mathrm{KOH}$ led to lower methyl content. The increase in the amount of catalyst 234 brings more methoxy free radicals, increases the contact opportunities between free radicals 235 and oils, and promotes the transesterification reaction. The maximum content of methyl ester 236 was obtained with $1.0 \% \mathrm{KOH}$. An excess amount of $\mathrm{KOH}$ would reduce the biodiesel yield, 237 for high $\mathrm{KOH}$ concentrations causes more triglycerides being involved in the saponification 238 reaction and brings about the formation of soap (Chhetri, Watts et al. 2008). 

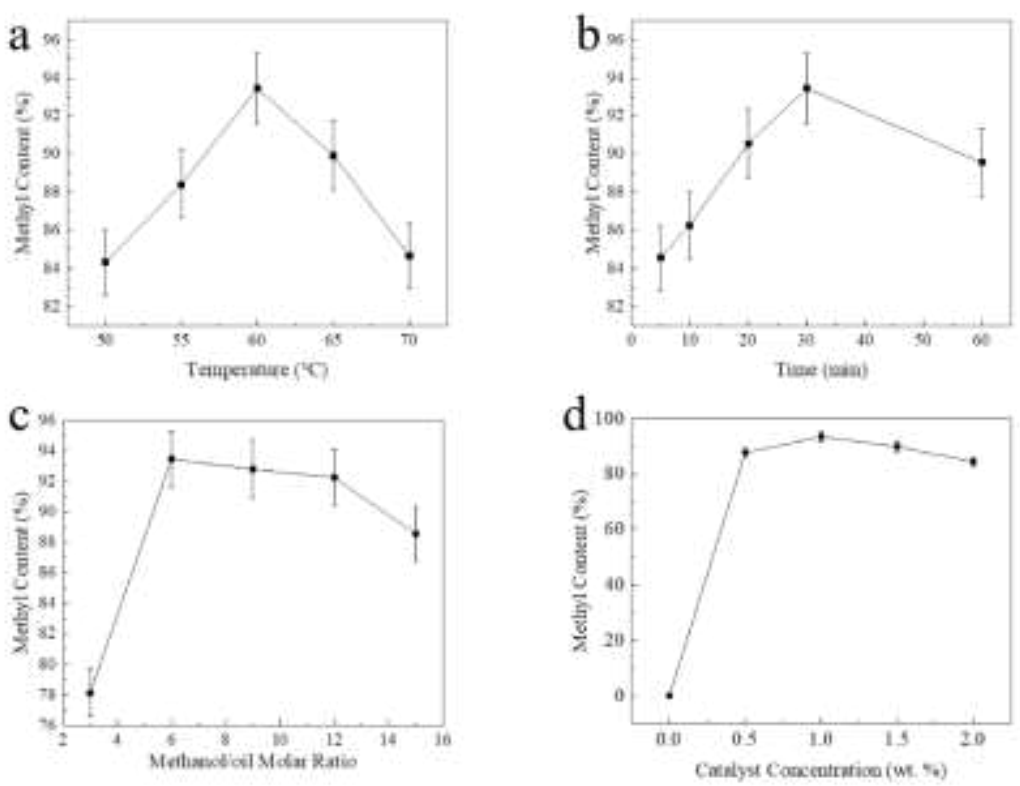

240 Fig.2. Effects of the process parameters (temperature, time, methanol /oils molar ratio

241 and KOH concentration).(a) Effect of temperature; (b) Effect of time; (c) Effect of

242 methanol/oils molar ratio; (d) Effect of catalyst concentration.

243 Experimental yield data were given as an input of the analysis of variance (ANOVA) in table

244 2. The results showed that the reaction time has no obvious effect on the transesterification

245 yield in EH process. The significant terms influencing the biodiesel yield in decreasing order

246 are catalyst amount, methanol/oil molar ratio and reaction temperature.

247 Table 2 ANOVA analysis of EH process

\begin{tabular}{|c|c|c|c|c|c|c|}
\hline Source of & & Degrees of & & & & F critical \\
\hline & Variance & & Mean square error & F value & $P$ value & \\
\hline difference & & freedom & & & & value \\
\hline Time & 0.004321 & 4 & 0.001080 & 1.863 & 0.1663 & 3.007 \\
\hline Tempreature & 0.009093 & 4 & 0.002273 & 3.920 & 0.02100 & 3.007 \\
\hline RO & 490.4 & 4 & 122.6 & 38.39 & 4.864E-06 & 3.478 \\
\hline
\end{tabular}




\begin{tabular}{ccccccc}
\hline Source of & \multicolumn{3}{c}{ Degrees of } & & \multicolumn{2}{c}{ F critical } \\
difference & Variance & & Mean square error & F value & P value & value \\
\hline CA & & freedom & & & & \\
\hline
\end{tabular}

248 RO stands for methanol/oil molar ratio; CA stands for catalyst amount.

$249 \quad 3.2 .2$ Biodiesel yield of MW process

250 In case of MW, the optimization of the factors including microwave power, reaction time,

251 catalyst amount and methanol/oil molar ratio. Fig.3 shows the variation into FAME yield. The

252 maximum biodiesel yield obtained from MW technique is $80.66 \%$, under the condition of

$253200 \mathrm{~W}, 5 \mathrm{~min}$, the dosage of $1 \mathrm{wt} . \% \mathrm{KOH}$ and the methanol/oil molar ratio of 9:1. The detailed

254 results are shown in table $\mathrm{S} 2$.

255

256
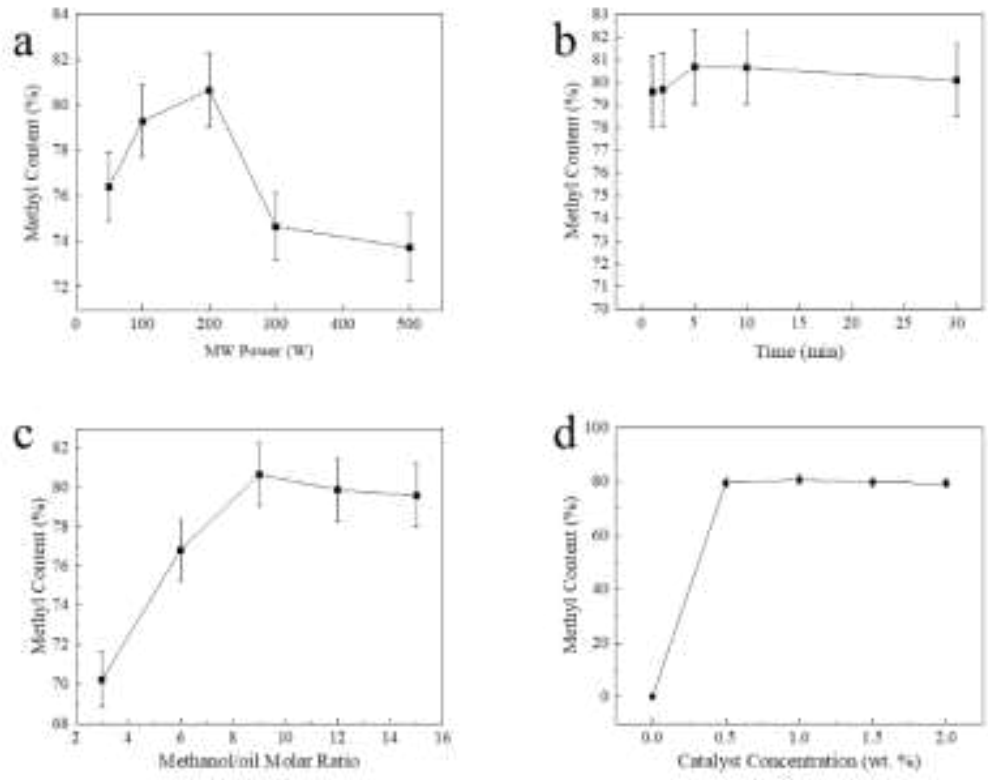

ratio and $\mathrm{KOH}$ concentration).(a) Effect of microwave power; (b) Effect of time; (c)

260 Effect of methanol/oils molar ratio; (d) Effect of catalyst concentration.

261 The curves of MW process were very similar to those of the EH process, but there was

262 difference in value. The reaction time in MW technique was sustainably reduced, while the 263 amount of methanol required was higher. These was because of that microwave would affect 264 dipole rotation and ion migration, improve the thermal conductivity and convection current of 265 the mixture. (Manco, Giordani et al. 2012, Sharma, Kodgire et al. 2021) This effect accelerated 266 molecular level heating, would increase the volatilization of methanol while shortening the 267 reaction time. In MW process, the temperature rised very sharply, breaking through the boiling 268 point of methanol after 2 minutes; even if the temperature rise slowed down after 5 minutes, 269 the system temperature had already exceeded $80^{\circ} \mathrm{C}$ (Fig.4). Too high reaction temperature made methanol boil violently, which seriously affected the condensation effect. Therefore, the final yield was lower than EH process. 


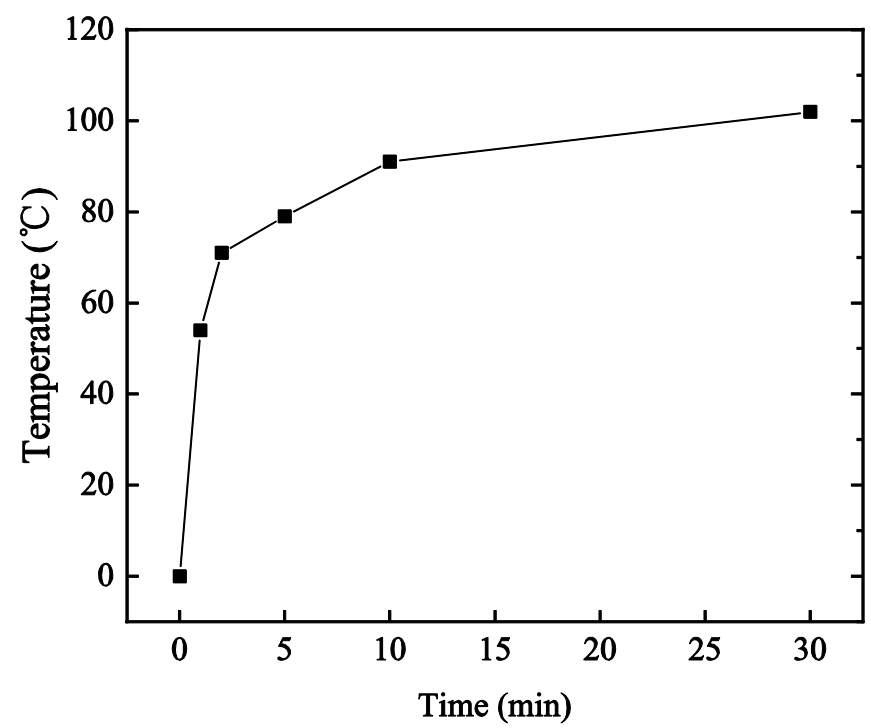

272

\section{Fig.4 Temperature rising of the reaction system in MW process}

274 Experimental yield data were given as an input of the analysis of variance (ANOVA) in table

275 3. According to the results, in MW process, the microwave power and reaction time would not

276 significantly affect the reaction yield. The significant terms influencing the biodiesel yield in

277 decreasing order are catalyst amount, and methanol/oil molar ratio. It was worth noting that the

278 probability value of catalyst amount were almost the same in EH process and MW process.

279 Table 3 ANOVA analysis of MW process

\begin{tabular}{ccccccc}
\hline Source of difference & Variance & Degrees of freedom & Mean square error & F value & P value & F critical value \\
\hline Time & 7.077 & 2 & 3.539 & 0.4435 & 0.6566 & 4.459 \\
Power & 113.5 & 4 & & & & 3.838 \\
RO & 220.5 & 4 & 28.38 & 3.557 & 0.0597 & 3.478 \\
CA & $1528 \mathrm{E}+01$ & 4 & 55.12 & 22.76 & $5.223 \mathrm{E}-05$ & 3.478 \\
\hline
\end{tabular}

280 RO stands for methanol/oil molar ratio; CA stands for catalyst amount. 


\subsubsection{The effect of water in both reaction system}

282 Oleic acid triglyceride was used as model compound to determine the impact of water content

283 on the methyl ester content. The experiments were conducted in the presence of water ranging

284 from $0.05 \%$ to $0.5 \% \mathrm{w} / \mathrm{w}$ of oil. The other parameters were in constant with the experiments

285 where the maximum methyl content was obtained in the above sections. The results are

286 represented in Fig.5. For both $\mathrm{CH}$ and MW techniques, water content had obviously negative

287 effect on biodiesel yield. Moisture would promote the saponification reaction was the main

288 reason of FAME yield decrease. In the case of MW, water molecules would move quickly

289 along the direction of the constantly changing microwave field, thereby accelerating the

290 saponification and hydrolysis reactions. Higher reaction temperature would also increase

291 saponification and reduce the yield of biodiesel. Thus, MW technique has more stringent

292 requirements on the water content of the feedstock oil, when WCO is used as a reactant, more

293 stringent pretreatment of water removal is required.
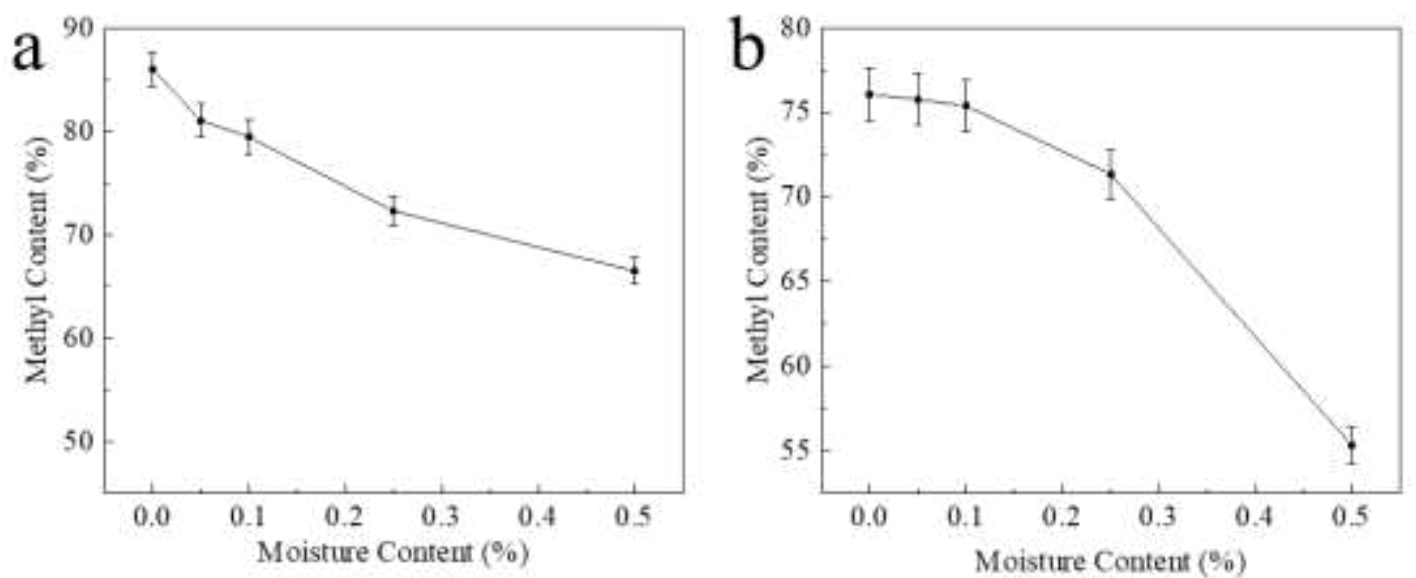

295 Fig.5 Effect of catalyst concentration on the methyl content in the biodiesel sample

$296 \quad 3.3$ Kinetics Analysis 
297 For $\mathrm{CH}$ and MW, the rate constants of the transesterification reaction under different 298 temperature or different microwave power were respectively determined by curve fitting the

299 reaction rate equations with the biodiesel yield. Performing kinetic calculations according to

3002.5 , the reaction rate constant of $\mathrm{CH}$ process was found to increase from $0.3479 \mathrm{~min}^{-1}$ to 0.4048

$301 \mathrm{~min}^{-1}$. The reaction rate constant at $60^{\circ} \mathrm{C}$ was 0.3737 . The reaction rate constant of MW process

302 increased from $3.623 \mathrm{~min}^{-1}$ to $9.965 \mathrm{~min}^{-1}$. The reaction rate constant at 200W was $9.247 \mathrm{~min}^{-}$

$303{ }^{1}$. It is worth noting that the reaction rate constant of the MW process reached the maximum

304 when the microwave power was $300 \mathrm{~W}$, and decreased at $500 \mathrm{~W}$. It is observed that the k value

305 was approximately 10 to 20 times higher respectively in the case MW process than that of $\mathrm{CH}$.

306 The higher rate constant means a faster reaction rate, requiring lower activation energy.

307 (Sharma, Kodgire et al. 2021)

308 Activation energy values derived from Arrhenius plots using Eq. 8 for the both techniques are

309 shown in Fig 6. The activation energy for $\mathrm{CH}$ and MW process are found to be $6768 \mathrm{~J} \cdot \mathrm{mol}^{-1}$

310 and $503.4 \mathrm{~J} \cdot \mathrm{mol}^{-1}$. Microwave heating greatly reduced the activation energy of the reaction.

311

312

313

314

315

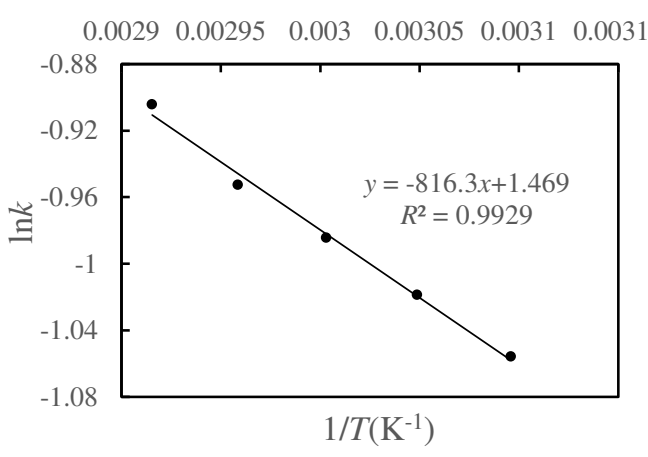

(a) $\mathrm{CH}$

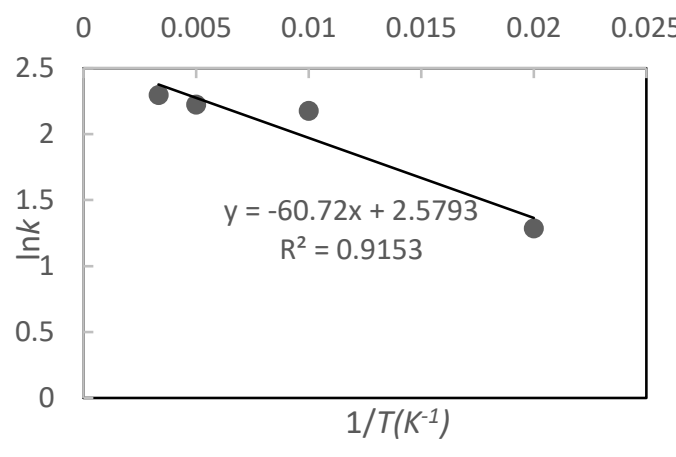

(b)MW

Fig.6 Linear fitting of $\operatorname{lnk}$ to $1 / T$ in transesterification reaction

\subsection{Reaction efficiency comparison}


316 A comparative study has been done on different biodiesel producing process as shown in table

317 6. The main advantage of homogeneous base-catalyzed transesterification is that the reaction

318 temperature is low, the reaction time is short, the catalyst and methanol are added in a small

319 amount, and the production cost can be saved. There is a large difference in FAME yield due

320 to the difference in raw materials. Compared with other research, this study still has the

321 advantages of high speed and low production cost, but FAME yield is slightly insufficient. This

322 is likely due to the small amount of un-removed moisture contained in the WCO.

323 The acid catalysed transesterification or two-step esterification- trans-esterification has a wider

324 application range, can adapt to the possible high free fatty acid content and high water content

325 of WCO, and can obtain high FAME yield under strong acid catalyzed conditions, but the

326 reaction conditions are harsh and the methanol consumption is larger. As compared to these

327 reported data, at present experiment work biodiesel yield 93\% was obtained at 30min reaction

328 time, $60^{\circ} \mathrm{C}$ reaction time and $6: 1$ methanol/ oil ratio for the composition and physical properties

329 of WCO in EH process.

330 The data in 3.2 shows that in this study, the transesterification yield of the MW process is lower

331 than that of the EH process. The possible reason is that methanol is more polar and has a strong

332 ability to absorb microwaves. The methanol in the system heats up rapidly, becoming a "hot

333 spot" in the reaction system, and rapidly evaporates above its boiling point, causing the

334 methanol concentration of the reaction system to drop, which affects subsequent

335 transesterification reactions proceed; while triglycerides are just the opposite. They are less

336 polar and have a weak microwave absorbing ability, which becomes a "cold spot" in the 
337 reaction system, making the rate of reaction with methanol slower; in addition, with As the

338 reaction progresses, the polarity of the intermediate products and products of the reaction

339 system is smaller than the polarity of the initial reactants, which leads to the gradual decrease

340 of the thermal and non-thermal effects of the microwave. Compared with previous studies, the

341 transesterification yield of the MW process in this study is significantly lower $(93.06 \%$ vs

342 80.66\%) (Gunawan, Aznury et al. 2019, Ibrahim, Omilakin et al. 2019). This shows that the

343 WCO used in this study is less adaptable to microwaves, and the most important factor is the

344 water content of WCO.

345 Table 6

346 Comparison of different biodiesel produce process.

\begin{tabular}{|c|c|c|c|c|c|c|c|}
\hline Raw Material & $\begin{array}{l}\text { Reaction } \\
\text { Method }\end{array}$ & $\begin{array}{l}\text { Molar Radio } \\
\text { (oil: alcohol) }\end{array}$ & $\begin{array}{l}\text { Reaction } \\
\text { Temperature } \\
\left({ }^{\circ} \mathrm{C}\right)\end{array}$ & $\begin{array}{l}\text { Reaction } \\
\text { Time } \\
(\mathrm{min})\end{array}$ & $\begin{array}{l}\text { Catalyst } \\
\text { Concentration } \\
\text { (wt. \%) }\end{array}$ & $\begin{array}{l}\text { FAME } \\
\text { yield } \\
(\%)\end{array}$ & Ref. \\
\hline $\begin{array}{l}\text { Silurus } \\
\text { triostegus } \\
\text { Heckel fish oil }\end{array}$ & $\mathrm{KOH}$ & 6.0 & 32.0 & 60 & 0.50 & 96.0 & $\begin{array}{l}\text { (Fadhil and } \\
\text { Ali 2013) }\end{array}$ \\
\hline Waste frying oil & $\mathrm{KOH}$ & 7.3 & 55.3 & - & 0.50 & 96.3 & $\begin{array}{l}\text { (Harabi, } \\
\text { Bouguerra } \\
\text { et al. 2019) }\end{array}$ \\
\hline $\begin{array}{l}\text { Garcinia } \\
\text { gummi-gutta } \\
\text { seed oil (GGO) }\end{array}$ & $\mathrm{KOH}$ & 6.0 & 55.0 & 90 & 1.6 & 97.0 & $\begin{array}{l}\text { (Rajagopala } \\
\text { char, Joshi } \\
\text { et al. 2019) }\end{array}$ \\
\hline Linseed oil & $\mathrm{KOH}$ & $20.0 \mathrm{wt} . \% *$ & 60.0 & - & 1.5 & 88.0 & $\begin{array}{l}\text { (Akram, } \\
\text { Singh et al. } \\
2019 \text { ) }\end{array}$ \\
\hline WCO & $\mathrm{K} 2 \mathrm{O}-\mathrm{CaO}$ & 18.0 & - & 300 & 4.0 & 89.5 & $\begin{array}{l}\text { (Zul, } \\
\text { Ganesan et } \\
\text { al. 2019) }\end{array}$ \\
\hline $\begin{array}{l}\text { WCO (through } \\
\text { acid-catalyzed }\end{array}$ & $\mathrm{KOH}$ & 3.0 & 50.0 & $360+50$ & 1.0 & 94.0 & $\begin{array}{l}\text { (Sahar, } \\
\text { Sadaf et al. }\end{array}$ \\
\hline $\begin{array}{l}\text { pre- } \\
\text { esterification) }\end{array}$ & & & & & & & 2018) \\
\hline
\end{tabular}




\begin{tabular}{|c|c|c|c|c|c|c|c|}
\hline Raw Material & $\begin{array}{l}\text { Reaction } \\
\text { Method }\end{array}$ & $\begin{array}{l}\text { Molar Radio } \\
\text { (oil: alcohol) }\end{array}$ & $\begin{array}{l}\text { Reaction } \\
\text { Temperature } \\
\left({ }^{\circ} \mathrm{C}\right)\end{array}$ & $\begin{array}{l}\text { Reaction } \\
\text { Time } \\
(\mathrm{min})\end{array}$ & $\begin{array}{l}\text { Catalyst } \\
\text { Concentration } \\
(\text { wt. \%) }\end{array}$ & $\begin{array}{l}\text { FAME } \\
\text { yield } \\
(\%)\end{array}$ & Ref. \\
\hline WCO & $\mathrm{H}_{2} \mathrm{SO}_{4}$ & 20.0 & 95.0 & 600 & 4.0 & 90.0 & $\begin{array}{l}\text { (Wang, Ou } \\
\text { et al. 2006) }\end{array}$ \\
\hline $\begin{array}{l}\text { WCO (through } \\
\text { acid-catalyzed } \\
\text { pre- } \\
\text { esterification) }\end{array}$ & Alkali & 10.0 & 95.0 & 240 & 2.0 & 97.2 & $\begin{array}{l}\text { (Wang, Ou } \\
\text { et al. 2006) }\end{array}$ \\
\hline WCO & $\mathrm{KOH}$ & 6.0 & 60.0 & 30 & 1.0 & 93.4 & This study \\
\hline
\end{tabular}

347 -Indicates that the component is not reported

\section{Conclusions}

349 This study systematically compared the influencing factors and effects of the alkali-catalyzed

350 transesterification reaction of waste edible oils under EH and MW process, then compared the

351 results with previous studies, and explained the possible reasons for the decrease in yield under

352 MW conditions in this study eventually. The specific conclusions are list as follows.

353 The maximum FAME yield of $\mathrm{CH}$ process appeared at the reaction temperature is $60{ }^{\circ} \mathrm{C}$, the

354 reaction time is $30 \mathrm{~min}$, the molar ratio of alcohol to oil is $6: 1$, and the catalyst concentration

355 is $1.0 \%$, reaches $93.4 \%$. The maximum biodiesel yield obtained from MW technique is $80.66 \%$,

356 under the condition of $200 \mathrm{~W}, 5 \mathrm{~min}, 1 \mathrm{wt} . \% \mathrm{KOH}$ and the methanol/oil molar ratio of 9:1.

357 Compared with the $\mathrm{CH}$ process, microwave heating can shorten the reaction time, but will

358 increase the consumption of methanol, and the final yield will also decrease. The best catalyst

359 percentages for $\mathrm{CH}$ process and MW process are the same. And one-way analysis of variance

360 results showed that the biodiesel yield was witnessed to be very sensitive to methanol/oil molar

361 ratio and catalyst weight $\%$ for both $\mathrm{CH}$ and $\mathrm{MW}$ techniques. 
362 The activation energy of $\mathrm{CH}$ and MW were respectively determined by the pseudo-first-order

363 kinetic modeling and pseudo-second-order kinetic modeling. The activation energy for $\mathrm{CH}$ and

364 MW process are found to be $6768 \mathrm{~J} \cdot \mathrm{mol}^{-1}$ and $503.4 \mathrm{~J} \cdot \mathrm{mol}^{-1}$. Microwave heating greatly

365 reduced the activation energy of the reaction. However, the transesterification yield of the MW

366 process is lower than that of the $\mathrm{CH}$ process.

367 Compared with other biodiesel producing process, $\mathrm{CH}$ process in this study has the advantages

368 of high speed and low production cost, while FAME yield is slightly insufficient. This is likely

369 due to the small amount of un-removed moisture contained in the WCO.

\section{Declarations}

371 - Ethics approval and consent to participate is not applicable;

372 Consent for publication is not applicable;

373 - All data generated or analysed during this study are included in this published article [and

374 its supplementary information files];

375 The authors declare that they have no competing interests;

376 - The works were financially supported by Key Project in the National Science \&

377 Technology Pillar Program in China (grant number: 2010BAK69B24).

378 - All authors contributed to the study conception and design. Wj L, FW and Gm L performed

379 the material preparation, data collection and analysis. The first draft of the manuscript was

380 written by Wenjing Li. Wz H, Hc Z and Jw $\mathrm{H}$ critically revised the work. All authors read 381 and approved the final manuscript.

\section{References}



homogeneous and heterogeneous catalyst for biodiesel production." Journal of the Taiwan Institute of Chemical Engineers 43(1): 89-94.

Akram, W., Y. Singh, A. Sharma and N. K. Singh (2019). "Experimental studies on performance and exhaust emission characteristics of a diesel engine fuelled with diesel-linseed oil methyl ester (LOME) blends." Energy Sources Part a-Recovery Utilization and Environmental Effects. Bouaid, A., R. Vázquez, M. Martinez and J. Aracil (2016). "Effect of free fatty acids contents on biodiesel quality. Pilot plant studies." Fuel 174: 54-62.

Bussness, S. (2012). "Gutter oil profit chain revealed: up to 300\%." from http://business.sohu.com/20120905/n352362645.shtml.

393 Canakci, M. and J. Van Gerpen (1999). "Biodiesel production via acid catalysis." Transactions of the Asae 42(5): 1203-1210.

Chhetri, A. B., K. C. Watts and M. R. Islam (2008). "Waste Cooking Oil as an Alternate Feedstock for Biodiesel Production." Energies 1(1): 3-18.

397 China, N. B. o. S. o. (2018). Production of refined edible vegetable oil.

398 Chuah, L. F., J. J. Klemes, S. Yusup, A. Bokhari and M. M. Akbar (2017). "A review of cleaner intensification 399 technologies in biodiesel production." Journal of Cleaner Production 146: 181-193.

400 Cvengros, J. and Z. Cvengrosova (2004). "Used frying oils and fats and their utilization in the production of methyl esters of higher fatty acids." Biomass \& Bioenergy 27(2): 173-181.

402 Elango, R. K., K. Sathiasivan, C. Muthukumaran, V. Thangavelu, M. Rajesh and K. Tamilarasan (2019).

403 "Transesterification of castor oil for biodiesel production: Process optimization and characterization." 404 Microchemical Journal 145: 1162-1168.

405 Fadhil, A. B. and L. H. Ali (2013). "Alkaline-catalyzed transesterification of Silurus triostegus Heckel fish oil: 406 Optimization of transesterification parameters." Renewable Energy 60: 481-488.

407 Farid, M. A. A., M. A. Hassan, Y. H. Taufiq-Yap, M. L. Ibrahim, M. R. Othman, A. A. M. Ali and Y. Shirai 408 (2017). "Production of methyl esters from waste cooking oil using a heterogeneous biomass-based catalyst." 409 Renewable Energy 114: 638-643.

410 fei, z. and n. maiqian (2011). "Study on the production of single cell protein by discarded edible oils and fats." 411 Ecotechnology 17(3): 1-4.

412 Gunawan, I., M. Aznury and A. Husaini (2019). "Synthesis Biodiesel from Waste Cooking Oil with Microwave 413 Irradiation Method as Alternative Renewable Energy Source." Symposium of Emerging Nuclear Technology and 414 Engineering Novelty (Senten 2018) 1198.

415 Gupta, A. R. and V. K. Rathod (2018). "Waste cooking oil and waste chicken eggshells derived solid base catalyst 416 for the biodiesel production: Optimization and kinetics." Waste Management 79: 169-178.

417 Harabi, M., S. N. Bouguerra, F. Marrakchi, L. P. Chrysikou, S. Bezergianni and M. Bouaziz (2019). "Biodiesel 418 and Crude Glycerol from Waste Frying Oil: Production, Characterization and Evaluation of Biodiesel Oxidative 419 Stability with Diesel Blends." Sustainability 11(7).

420 Ibrahim, A. P., R. O. Omilakin and E. Betiku (2019). "Optimization of microwave-assisted solvent extraction of 421 non-edible sandbox (Hura crepitans) seed oil: A potential biodiesel feedstock." Renewable Energy 141: 349-358. 422 Jia, L., H. Xiangfeng, L. Lijun, Y. Na, G. Sainan, C. Xuyuan, Y. Dianhai and Z. Qi (2009). "Study on Dietziasp. 423 S-JS-1 Production of Bio-Demulsifier by Using Waste Oil." Microbiology bulletin 36(4): 491-497.

424 Knothe, G. (2005). "Dependence of biodiesel fuel properties on the structure of fatty acid alkyl esters." Fuel 425 Processing Technology 86(10): 1059-1070. 
Kulkarni, M. G. and A. K. Dalai (2006). "Waste cooking oil-an economical source for biodiesel: A review." Industrial \& Engineering Chemistry Research 45(9): 2901-2913. Leung, D. Y. C. and Y. Guo (2006). "Transesterification of neat and used frying oil: Optimization for biodiesel production." Fuel Processing Technology 87(10): 883-890. Ma, F. and M. A. Hanna (1999). "Biodiesel production: a review 1." Bioresource Technology 70(1): 1-15. Maddikeri, G. L., A. B. Pandit and P. R. Gogate (2012). "Intensification Approaches for Biodiesel Synthesis from Waste Cooking Oil: A Review." Industrial \& Engineering Chemistry Research 51(45): 14610-14628. Manco, I., L. Giordani, V. Vaccari and M. Oddone (2012). "Microwave technology for the biodiesel production: Analytical assessments." Fuel 95(1): 108-112. Mardhiah, H. H., H. C. Ong, H. H. Masjuki, S. Lim and H. V. Lee (2017). "A review on latest developments and future prospects of heterogeneous catalyst in biodiesel production from non-edible oils." Renewable \& Sustainable Energy Reviews 67: 1225-1236.

438 Math, M. C., S. P. Kumar and S. V. Chetty (2010). "Technologies for biodiesel production from used cooking oil — A review." Energy for Sustainable Development 14(4): 339-345.

440 Mercy Nisha Pauline, J., R. Sivaramakrishnan, A. Pugazhendhi, T. Anbarasan and A. Achary (2021). "Transesterification kinetics of waste cooking oil and its diesel engine performance." Fuel 285: 119108.

442 Milano, J., H. C. Ong, H. H. Masjuki, A. S. Silitonga, W. H. Chen, F. Kusumo, S. Dharma and A. H. Sebayang 443 (2018). "Optimization of biodiesel production by microwave irradiation-assisted transesterification for waste 444 cooking oil- Calophyllum inophyllum oil via response surface methodology." Energy Conversion and Management 158(FEB.): 400-415.

446 Milano, J., H. C. Ong, H. H. Masjuki, A. S. Silitonga, F. Kusumo, S. Dharma, A. H. Sebayang, M. Y. Cheah and 447 C. T. Wang (2018). "Physicochemical property enhancement of biodiesel synthesis from hybrid feedstocks of 448 waste cooking vegetable oil and Beauty leaf oil through optimized alkaline-catalysed transesterification." Waste 449 Management 80: 435-449.

450 Motasemi, F. and F. N. Ani (2012). "A review on microwave-assisted production of biodiesel." Renewable \& 451 Sustainable Energy Reviews 16(7): 4719-4733.

452 Naylor, R. L. and M. M. Higgins (2017). "The political economy of biodiesel in an era of low oil prices." 453 Renewable \& Sustainable Energy Reviews 77: 695-705.

454 Peiro, L. T., G. V. Mendez and X. G. I. Durany (2008). "Exergy analysis of integrated waste management in the 455 recovery and recycling of used cooking oils." Environmental Science \& Technology 42(13): 4977-4981. Phan, A. N. and T. M. Phan (2008). "Biodiesel production from waste cooking oils." Fuel 87(17-18): 3490-3496. Putra, M. D., C. Irawan, Udiantoro, Y. Ristianingsih and I. F. Nata (2018). "A cleaner process for biodiesel production from waste cooking oil using waste materials as a heterogeneous catalyst and its kinetic study." Journal

460 Rajagopalachar, S., S. S. Joshi and R. P. Reddy (2019). "Biodiesel synthesis from Garcinia gumnii-qutto (L. 461 Robson) seed oil: fuel feasibility evaluation of a novel feedstock by homogeneous and heterogeneous 462 transesterification." Biofuels-Uk 10(3): 403-410.

463 Ramezani, K., S. Rowshanzamir and M. H. Eikani (2010). "Castor oil transesterification reaction: A kinetic study 464 and optimization of parameters." Energy 35(10): 4142-4148.

465 Sahar, S. Sadaf, J. Iqbal, I. Ullah, H. N. Bhatti, S. Nouren, R. Habib ur, J. Nisar and M. Iqbal (2018). "Biodiesel 466 production from waste cooking oil: An efficient technique to convert waste into biodiesel." Sustainable Cities and 467 Society 41: 220-226. 
Sharma, A., P. Kodgire and S. Singh Kachhwaha (2021). "An experimental investigation of the performance of biodiesel production techniques: Optimization, kinetics, and energy analysis." Thermal Science and Engineering Progress 22: 100842 .

471 Silitonga, A. S., A. H. Shamsuddin, T. Mahlia, J. Milano, F. Kusumo, J. Siswantoro, S. Dharma, A. H. Sebayang,

472 H. Masjuki and H. C. Ong (2020). "Biodiesel synthesis from Ceiba pentandra oil by microwave irradiation473 assisted transesterification: ELM modeling and optimization." Renewable Energy 146.

474 Uzun, B. B., M. Kılıç, N. Özbay, A. E. Pütün and E. Pütün (2012). "Biodiesel production from waste frying oils: 475 Optimization of reaction parameters and determination of fuel properties." Energy 44(1): 347-351.

476 Wang, Y., S. Y. Ou, P. Z. Liu, F. Xue and S. Z. Tang (2006). "Comparison of two different processes to synthesize biodiesel by waste cooking oil." Journal of Molecular Catalysis a-Chemical 252(1-2): 107-112.

478 Xingguo, W. (2013). Oil Chemistry. Beijing, Beijing Science Press.

479 Yao, Z. and E. Min (2010). "A double-edged sword of the discarded edible oils:Harmful pollutants or resources 480 utilization." Natural Gas Industry 30(5): 123-128.

481 Yen, H. W., I. C. Hu, C. Y. Chen, S. H. Ho, D. J. Lee and J. S. Chang (2013). "Microalgae-based biorefinery 482 From biofuels to natural products." Bioresource Technology 135: 166-174.

483 Yeong, S. P., M. C. Law, K. Y. You, Y. S. Chan and V. C. C. Lee (2019). "A coupled electromagnetic-thermal484 fluid-kinetic model for microwave-assisted production of Palm Fatty Acid Distillate biodiesel." Applied Energy 485 237: 457-475.

486 Yinxia, Q., C. Jian and L. Changhai (2009). "Advances in the production of single cell proteins by fermentation 487 using waste resources." Food industry technology(5): 366-369.

488 Zhang, L., B. Sheng, Z. Xin, Q. Liu and S. Sun (2010). "Kinetics of transesterification of palm oil and dimethyl 489 carbonate for biodiesel production at the catalysis of heterogeneous base catalyst." Bioresour Technol 101(21): $490 \quad 8144-8150$.

491 Zhang, R., P. X. Pham, S. Kook and A. R. Masri (2019). "Influence of biodiesel carbon chain length on in-cylinder 492 soot processes in a small bore optical diesel engine." Fuel 235: 1184-1194.

493 Zul, N. A., S. Ganesan and M. H. Hussin (2019). "Application of K-Impregnated Staghorn Coral as Catalyst in 494 the Transesterification of Waste Cooking Oil." Sains Malaysiana 48(4): 803-811. 


\section{Supplementary Files}

This is a list of supplementary files associated with this preprint. Click to download.

- SupplementaryInformation.pdf 